\title{
Evaluation of Geometric Quality of 3D Models Obtained Automatically by Robotic RevoScan Device
}

\author{
Waldemar Bauer, Bartosz Mitka, Marcin Prochaska \\ Terramap Sp. z 0.0., ul. Rodziny Poganów 63, 32-080 Zabierzów
}

\begin{abstract}
The hereby article presents the results of an R\&D project implemented by the company Terramap. The result of the project is a measuring device for 3D digitization, enabling data acquisition and processing. A characteristic feature of the system is automatic acquisition of information on both object geometry (spatial digitization), as well as color information in the RGB color space on this object (high resolution digital photos). Software dedicated for the device allows for planning and controlling the data acquisition process and their processing, as well as development of the materials ready for presentation. Implementation of the results of the conducted tests by means of constructing a device on their basis with accompanying software enabled significant acceleration of the digitization works, and consequently reduction of unit costs of 3D digitization. In order to assess the geometric quality of the 3D models obtained automatically by the device reference measurements were performed for the selected objects. Such measurements were carried out using two methods: first the geometry of the tests objects was measured by means of a handheld 3D scanner Artec Eva, second a direct manual measurement of the characteristic dimensions of the test objects was performed using a caliper. The 3D models obtained from the RevoScan device and 3D scanner Artec Eva were fitted into each other, and then compared using tools available in the Geomagic Qualify software in modules Alignment and Analysis. Whereas the results of the manual measurements of the characteristic dimensions of the test objects were compared with the results of measurements of the same features carried out on the 3D models obtained from the RevoScan device. The obtained results represented in the form of tables and graphs. The performed tests confirm achieving the model accuracy better than $0.3 \mathrm{~mm}$ assumed in the project.
\end{abstract}

Keywords: digitization, 3D modeling, automation, measurement uncertainty

\section{Introduction}

Many authors of publications pay attention to the obstacles to creating virtual collections such as: difficulty of building virtual $3 \mathrm{D}$ objects and the costs of such a technology $[7,8]$. Apart from that the features of digitized objects often create many problems such as the color of the surface, its type or gloss [8].

The main problem of the digitization works is finding appropriate proportions between the costs and workload and the

Autor korespondujący:

WaldemarBauer,wbauer@dephos.com

Artykuł recenzowany

nadesłany 19.03.2017 r., przyjęty do druku 02.06.2017 r. quality of the obtained result [8]. The developments performed manually are very time-consuming, whereas the ones performed using the simplest available tools not always meet all the expectations [2]. Solution to the above-mentioned problems is automation of the performed works to the highest possible extent, application of advanced algorithms for data acquisition, orientation and filtration, as well as texturing of the obtained 3D models [8].

In order to perform 3D modeling of small objects with a complicated form it is recommended to use meshes that comprise a topological triangle or polygon mesh, which enables accurate representation of the surface while capturing all the details. According to literature dense mesh is generated based on point cloud that may be achieved as a result of ground-based laser scanning or processing of digital ground-based photos (Structure From Motion), taken with a proper longitudinal and transverse coverage $[4,6]$.

Building of a 3D model on the basis of a Structure From Motion method requires application of a strict procedure for 
implementation and processing of the photos, in which we should first of all ensure proper longitudinal and transverse coverage between the subsequent photos. What is more, as the authors point out [6] in order to build a 3D model it is necessary to know the parameters for internal orientation of the camera that may be determined in an independent calibration process or in the course of fitting the photos with the use of the characteristic points on the subsequent photos.

In many scientific publications we may find proposals for digitization solutions [8], as well as particular examples for implementation of digitization works [3], and the analysis for their accuracy [1]. The hereby publication presents the results of comparative test of the models obtained using the RevoScan device and a 3D scanner Artec Eva. The device concept and the results of test developments are presented in the publication "RevoScan - automatic device for 3D digitization - conception, application, test results" [5].

The device consists of the following elements (Fig. 1):

- glass turntable,

- two measuring columns that enable camera movement in the horizontal and vertical plane,

- camera head with the possibility of adjusting the tilt angle relative to the table,

- digital camera with movable polarization filter,

- the polarized light background,

- the shadeless tent,

- photographic lighting set - continuous or flash, device control module (servomotor and step engine controllers),

- control software for data capturing and processing.

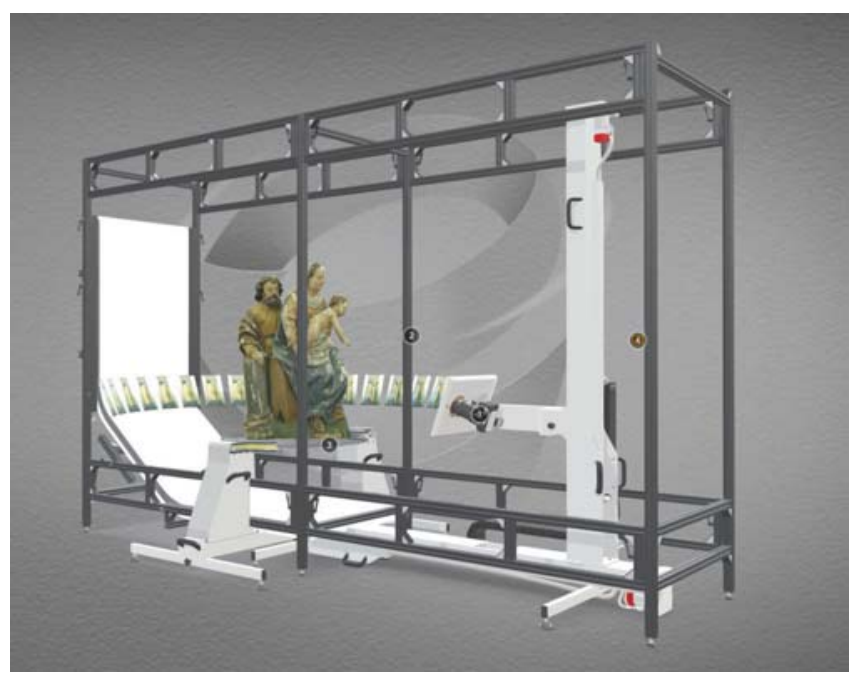

Fig. 1. RevoScan device: 1. Camera and camera head, 2. Construction of the shadeless tent and background, 3. Turntable, 4 . Security switch [www.revoscan.com]

Rys. 1. Urządzenie RevoScan: 1. Kamera i głowica kamery, 2. Konstrukcja namiotu bezcieniowego i tła, 3. Stół obrotowy, 4. Wyłącznik bezpieczeństwa [www.revoscan.com]

Dimensions of the device are scalable according to the needs of the customer. The turntable diameter varies from $600 \mathrm{~mm}$ to $1200 \mathrm{~mm}$ and its lifting capacity can be up to $150 \mathrm{~kg}$. Length of the measuring columns is $2000 \mathrm{~mm}$ be default, with the possibility of extension. The maximum dimensions of the digitized object with standard setup are: $1100 \mathrm{~m}$ width and $1500 \mathrm{~mm}$ height. During the measurement, a set of high-resolution images with a field pixel size of $0.1 \mathrm{~mm}$ to $0.3 \mathrm{~mm}$ (depending on the shooting distance and focal length of the lens used) is automatically acquired.

The device in its basic configuration performs digitization of objects in a form of a sequence of spherical, cylindrical or elliptical photography, depending on the geometry of the measured

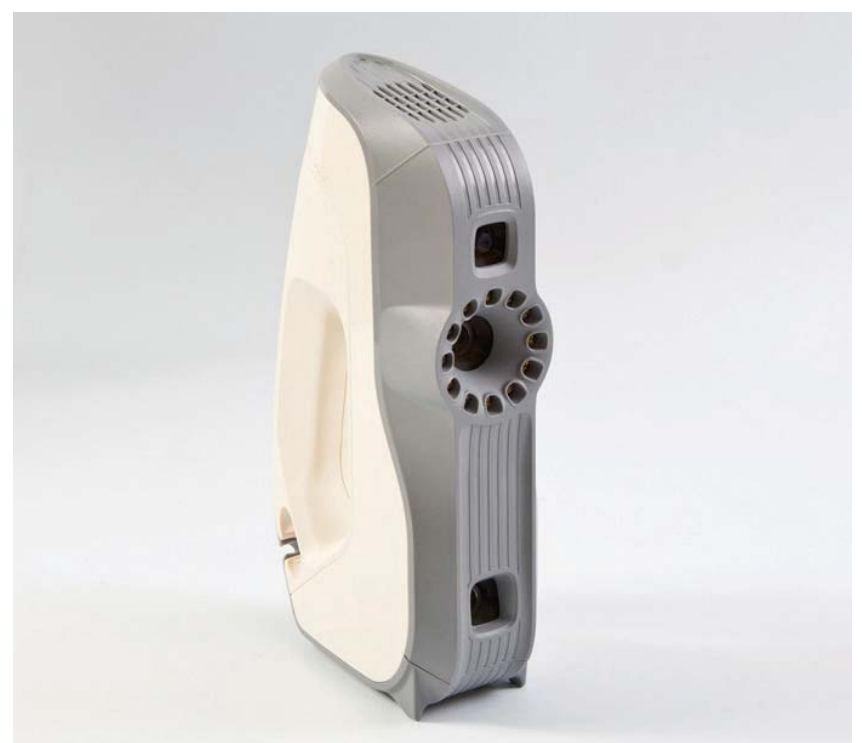

Fig. 2. Artec Eva 3D scanner [Source: Hexagon Group] Rys. 2. Skaner 3D Artec Eva [Żróło: Hexagon Group]

object. In addition to camera location resulting from the "flight plan" defined by the camera operator it is also possible to specify the camera location manually for a single photograph within the scope of a working area. An option of disconnection of measuring columns from the table with a simultaneous rotation of a vertical measuring column by $90^{\circ}$ is a solution that additionally increases the capabilities of the device. Thus we obtain the possibility of automatic (acc. to the "flight plan" defined by the camera operator), acquisition of photographs for structural objects with vertical or horizontal orientation, such as e.g. reliefs.

Artec Eva (Fig. 2) is 3D scanner for professional use. Artec Eva is used in countless industries, including quality control, the automotive industry, medicine, heritage preservation, computer graphics, design, forensics, education, reverse engineering and architecture [9].

This scanner is characterized by a working distance in the range of 400-1000 mm, 3D spatial resolution up to $0.5 \mathrm{~mm}$, and 3D point accuracy up to $0.1 \mathrm{~mm}$. Allows you to export the results into a wide range of formats: OBJ, PLY, WRL, STL, AOP, ASCII, Disney PTX, E57, XYZRGB, CSV, DXF, XML [9].

\section{Elements influencing the geometric quality of 3D models}

We may distinguish two basic device components that influence the geometric quality of the obtained 3D models. These are mechanical and control components providing adequate precision and positional repeatability of the camera in relation to the digitized object. Appropriate procedure for data acquisition and processing and using software for this purpose complement these components.

The concept of mechanical solutions is presented in the publication [5]. The concept for implementation of the control of the device is presented below.

\subsection{The component for the control of the RevoScan device}

The quality of the model determined the repeatability of camera positioning, therefore in order to achieve this goal, Computerized Numerical Control devices (CNC) have been used in the RevoScan. CNC systems are now used for any precision process that can be described as a series of movements and operations. These include laser cutting, welding, friction stir welding, ultra- 


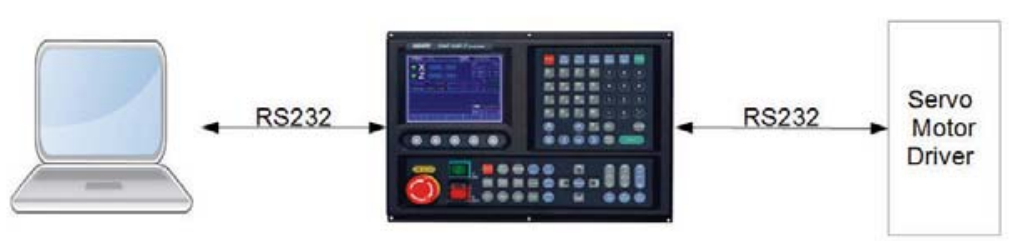

Fig. 3. The connection scheme for the system

Rys. 3. Schemat połączeń elementów systemu

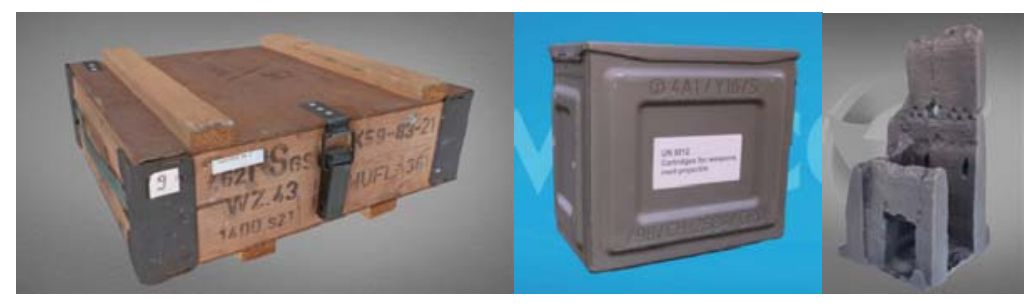

a)

b)

c)

Fig. 4. Selected test objects (3 of 8): a) wooden box (object no. 6 ), b) metal box (object no. 5), c) bronze casting (object no. 1)

Rys. 4. Wybrane obiekty testowe (3 z 8): a) skrzynka drewniana (obiekt nr 6), b) skrzynka metalowa (obiekt nr 5), c) odlew z brązu (obiekt nr 1)

sonic welding, flame and plasma cutting, bending and now to photo captures.

In the described device Hust CNC controller has been used. For the purpose of this application it was necessary to implement the relevant elements of the following protocol: device status, control of the movement of XYZA axes and movement of filter arms.

Hust CNC controller features 500k memory capacity for CNC main board, the LCD display with $800 \times 600$ resolution and a 16 color screen. It allows for simultaneous use of absolute and incremental programmable coordinates, self-diagnostic and error signaling function.

In this solution a servomotor with encoder feedback is used to move $\mathrm{X}$ and $\mathrm{Y}$ axes. To control the movement of the table and the camera a stepper motor has been implemented. The connection scheme for the system is presented in Fig. 3.

To conduct a correct process of digitalization a RevoScan device has been implemented:

- The automatic determination of a measurement plan (described by G-code),

- Control of movements of the arms and the camera,

- Control of opening and closing of the polarizing filter,

- Computer program to control process and tracking the Hust CNC status.

\section{The course of the experiment}

In order to assess the geometric quality of the 3D models obtained automatically by the device reference measurements were carried out for the selected objects. Such measurements were carried out using two methods:

- first, the geometry of the tests objects was measured by means of a handheld 3D scanner Artec Eva with 3D resolution up to $0.5 \mathrm{~mm}$ and $3 \mathrm{D}$ accuracy for point location up to $0.1 \mathrm{~mm}$; - second, a direct manual measurement of the characteristic dimensions of the test objects was performed using a caliper with the accuracy of the measurement up to $0,02 \mathrm{~mm}$.

The 3D models obtained from the REVOSCAN device and 3D scanner Artec Eva were fitted into each other, and then compared using tools available in the Geomagic Qualify software in modules Alignment and Analysis. Whereas the results of the manual measurements of the characteristic dimensions of the test objects were compared with the results of measurements of the same features carried out on the 3D models obtained from the RevoScan device.

\subsection{RevoScan - test objects and the method for obtaining the correct geometry}

Objects with different shapes and sizes made of various materials such as steel, wood, bronze, etc., as well as of different surface textures and various complex geometries were selected as test objects for the conducted tests (Fig. 4). In general 8 different objects were subject to measurements, 3D modeling and testing of the obtained geometry: bronze casting (object no. 1), basket for strawberries (object no. 2), machete (object no. 3), toad figurine (object no. 4), metal box (object no. 5), wooden box (object no. 6), wooden box covered with leather (object no. 7), wooden relief (object no. 8). The figure below (Fig. 1) presents the screenshots - of the selected ( 3 of 8 ) - obtained 3D models of different type of objects.

In order to ensure metricability and correct geometry of the generated 3D models, in the course of acquisition of the photos by the device the coordinates of the specific camera locations in the table layout are recorded and an additional set of photos is taken including calibration objects with clearly specified geometry (Fig. 5). The beginning of the device coordinate system is defined in the rotation axis of the tabletop. $\mathrm{Z}$ coordinate adopts 0 value for the upper surface of the tabletop. The direction of the $-\mathrm{Y}$ axis conforms to the direction of the horizontal measuring column of the device, and the defined coordinate system is a mathematical one.

The use in photography processing - in Agisoft PhotoScan software - of the known means for image projections and application of calibration object dimensions allows for obtaining 3D models with dimensions converging with the actual dimensions of the object. 3D models obtained based on the data acquired from the RevoScan device have been exported to OBJ format in order to verify their geometry.

\subsection{Parallel orientation of 3D models}

3D models obtained using an Artec Eva scanner have been developed in the Artec Studio 10 Professional, software dedicated to the scanner, and then exported to OBJ format.

The resulting 3D models from the RevoScan device and the Artec Eva scanner have been downloaded to the Geomagic Qualify 2013 software. Then their mutual fitting has been performed using Alignment module with Best Fit Alignment function. The table 1 below (Tab. 1) presents the precision parameters for fitting to the selected objects.

Table 1. Precision characteristics for orientation of 3D models Tabela 1. Charakterystyki dokładnościowe orientacji modeli 3D

\begin{tabular}{|c|c|c|c|}
\hline $\begin{array}{c}\text { Alignment } \\
\text { Name: }\end{array}$ & $\begin{array}{c}\text { Best fit alignment: } \\
\text { bronze_casting (1) }\end{array}$ & $\begin{array}{c}\text { Best fit } \\
\text { alignment: } \\
\text { metal_box (5) }\end{array}$ & $\begin{array}{c}\text { Best fit } \\
\text { alignment: } \\
\text { wooden_box (6) }\end{array}$ \\
\hline RMS Error & $0.12 \mathrm{~mm}$ & $0.33 \mathrm{~mm}$ & $0.057 \mathrm{~mm}$ \\
\hline Average Error & $0.68 \mathrm{~mm}$ & $0.48 \mathrm{~mm}$ & $0.055 \mathrm{~mm}$ \\
\hline
\end{tabular}

\subsection{Comparison of 3D models}

The next stage of the tests was verification of geometric quality of the obtained 3D models. For that purpose comparative tests of $3 \mathrm{D}$ models were performed obtained by means of the developed device, as well as a laser scanner Artec Eva. In order to compare the surface 3D Compare tool was used, available in the Geomagic Quality software in the Analysis module. For each of 
Table 2: The results of comparison of 3D models

Tabela 2. Wyniki porównania modeli 3D

\begin{tabular}{|c|c|c|c|}
\hline & $\begin{array}{c}\text { Reference Model bronze_casting_artec } \\
(1) \\
\text { Test Model bronze_casting__ } \\
\text { RevoScan_600k }\end{array}$ & $\begin{array}{c}\text { Reference Model metal_box_artec } \\
(5) \\
\text { Test Model metal_box__ } \\
\text { RevoScan_600k }\end{array}$ & $\begin{array}{c}\text { Reference Model wooden_box_artec } \\
(6) \\
\text { Test Model wooden_box__ } \\
\text { Revo Scan_600k }\end{array}$ \\
\hline $\begin{array}{l}\text { Average Deviation } \\
\text { (in plus/in minus) }\end{array}$ & $0.6 \mathrm{~mm} /-0.5 \mathrm{~mm}$ & $0.3 \mathrm{~mm} /-0.4 \mathrm{~mm}$ & $0.4 \mathrm{~mm} /-0.6 \mathrm{~mm}$ \\
\hline Standard Deviation & $0.7 \mathrm{~mm}$ & $0.5 \mathrm{~mm}$ & $0.7 \mathrm{~mm}$ \\
\hline
\end{tabular}

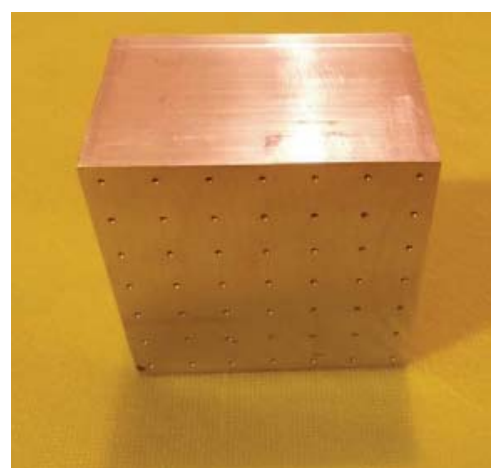

NO.

photoNoFilter_0_0.jpg 0,0000 photoNoFilter 0 - 1.jpg 0,1302

photoNoFilter_0_2.jpg 0,2565

photoNoFilter_0_3.jpg 0,3750

photoNoFilter_0_4.jpg 0,4820

$-0,7500 \quad 0,1500$

$-0,7386 \quad 0,1500$

$-0,7047 \quad 0,1500$

$-0,6495 \quad 0,1500$

$-0,5745 \quad 0.1500$

photoNoFilter_1_35.jpg -0,1302 -0,7386 0,6803

Fig. 5. Calibration object and a system of coordinates of the photos obtained in the table layout Rys. 5. Obiekt kalibracyjny i zestaw współrzędnych pozyskanych zdjęć w układzie stolika distribution analysis between the models allows for stating that more than $57 \%$ of them are within the range of $\pm 0.3 \mathrm{~mm}$, and more than $79 \%$ of deviations are smaller than $0.6 \mathrm{~mm}$. the greatest differences between the models are present in case of very small elements, sharp edges or deep slots. Similar results were obtained for the rests of the tested objects.

\subsection{Comparison of 3D models with direct object measurements}

the pair of meshes in the Analysis module a comparison of the $3 \mathrm{D}$ models was made, adopting a mesh obtained on the basis of the data from the laser scanner as a reference model, and the mesh obtained on the basis of digital photos as a tested model. The comparison was performed on the meshes composed of 600,000 vertexes. The results of comparison for the selected objects are included in Tab. 2.

Distribution of deviations between the models (for a wooden box, (6)) are illustrated by Figure no. 6 (Fig. 4). The deviation

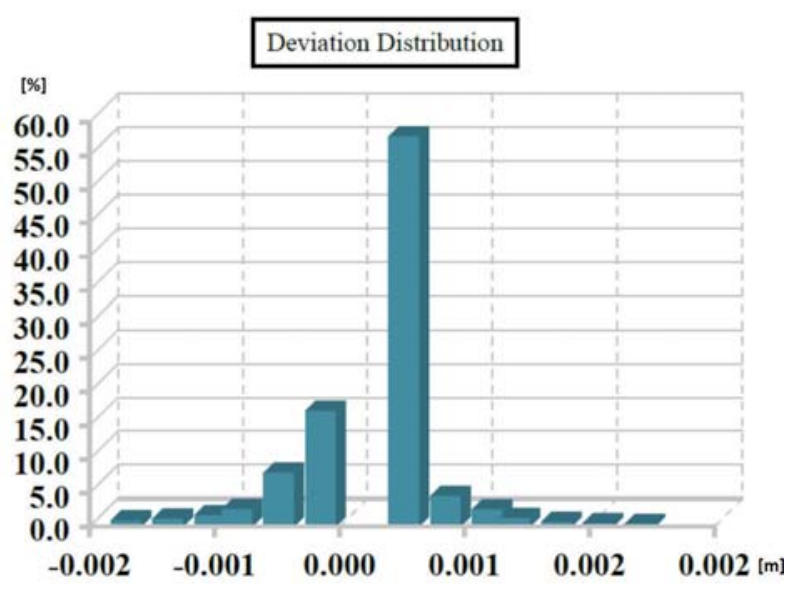

Fig. 5. Distribution of deviations between the models - wooden box Rys. 5. Rozkład odchyłek między modelami - skrzynka drewniana
Direct measurements of characteristic dimensions of the test objects were performed using a caliper with measurement accuracy of $\pm 0.02 \mathrm{~mm}$. the results of these measurements were compared with the results of the measurements of same elements obtained from cross-sections of 3D models from the RevoScan device. In general, over 150 measurements were performed for all the tested models. Table 3 includes the summary of the results obtained for the selected objects and all the tested models.

\section{Summary}

Summing up, we may say that 3D models obtained from the RevoScan device may similar spatial accuracy as the ones obtained from the handheld 3D scanner. The comparison of dimensions of 3D models with direct measurements indicated accuracy of model geometry at the level of $0.35 \mathrm{~mm}$, which in the terms of design assumptions amounting to $0.3 \mathrm{~mm}$ confirms achievement of the assumed goal.

Due to automation of the works at the stage of data acquisition and data processing and limitation of manual activities to a minimum, the process of digitization of $3 \mathrm{D}$ object was significantly reduced. It results in substantial increase in the efficiency of the process of digitization and at the same time reduction of its unit costs while the obtained quality of model geometry is comparable with models obtained on the basis of a handheld 3D scanner.

Table 3. The results of comparison of direct measurements with the measurements of 3D models

Tabela 3. Wyniki porównania pomiarów bezpośrednich z pomiarami modeli 3D

\begin{tabular}{|c|c|c|c|}
\hline Object & Bronze casting & Metal box & Wooden box \\
\hline Average difference & $0.34 \mathrm{~mm}$ & $0.35 \mathrm{~mm}$ & $0.33 \mathrm{~mm}$ \\
\hline Maximum difference & $0.77 \mathrm{~mm}$ & $0.76 \mathrm{~mm}$ & $0.72 \mathrm{~mm} \mathrm{~mm}$ \\
\hline Standard deviation & $0.26 \mathrm{~mm}$ & $0.22 \mathrm{~mm}$ & $0.25 \mathrm{~mm}$ \\
\hline
\end{tabular}




\section{Acknowledgments}

The tests have been carried out thanks to the funds from the Innovative Economy Operational Programme, 2007-2013, Measure 1.4 Support of goal-oriented projects, agreement UDA-POIG.01.04.00-12-124/11-00.

\section{Bibliography}

1. Fassi F., Fregonese L., Ackermann S., De Troia V., Comparison between laser scanning and automated $3 d$ modelling techniques to reconstruct complex and extensive cultural heritage areas. International Archives of the Photogrammetry, Remote Sensing and Spatial Information Sciences, Vol. XL-5/W1, 2013, 3D-ARCH 2013 - 3D Virtual Reconstruction and Visualization of Complex Architectures, 25-26 February 2013, Trento, Italy.

2. Kwoczyńska B., Rzepka A., Zastosowanie kamery niemetrycznej do modelowania obiektów małej architektury, Infrastruktura i Ekologia Terenów Wiejskich, PAN Oddział Kraków, Nr 2/II/2013, 31-41.

3. Menna F., Rizzi A., Nocerino E., Remondino F., Gruen A., High resolution $3 D$ modeling of the Behaim Globe, International Archives of the Photogrammetry, Remote Sensing and Spatial Information Sciences, Volume XXXIX-B5, 2012 XXII ISPRS Congress, 25 August - 01 September 2012, Melbourne, Australia.

4. Pluta M., Mitka B., Możliwości modelowania 3D na podstawie danych ze skaningu laserowego, „Episteme” Czasopismo Kulturalno-Naukowe, 22/2014 t. II, 2014, 137-146.
5. Prochaska M., Mitka B., RevoScan - Automatic Device for 3 D Digitisation: Concept, Application, Test Results, "Geomatics and Environmental Engineering", Vol. 10, No. 4, 2016, 81-87.

6. Reu J., Plets G., Verhoeven G., Smedt P., Bats M., Cherretté B., Maeyer W., Deconynck J., Herremans D., Laloo P., Meirvenne M., Clercq W., Towards a three-dimensional cost-effective registration of the archaeological heritage, "Journal of Archeological Science", Vol. 40, Iss. 2, 2013, 1108-1121.

7. Rizvic S., Sadzak A., Ramic-Brkic B. Hulusic V., Virtual museums and their public perception in Bosnia and Herzegovina, "International Archives of the Photogrammetry, Remote Sensing and Spatial Information Sciences", Vol. XXXVIII-5/W16, 2011 ISPRS Trento 2011 Workshop, 2-4 March 2011, Trento, Italy.

8. Zheng S., Zhoua Y., Huanga R., Zhoua L., Xua X., Wangb C., A method of 3D measurement and reconstruction for cultural relics in museums, "International Archives of the Photogrammetry, Remote Sensing and Spatial Information Sciences", Vol. XXXIX-B5, 2012 XXII ISPRS Congress, 25 August - 01 September 2012, Melbourne, Australia.

9. https://www.artec3d.com/files/pdf/ArtecScanners-Booklet-EURO.pdf.

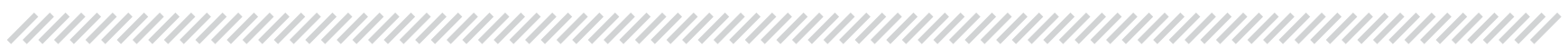

\section{Ocena jakości geometrycznej modeli 3D uzyskanych automatycznie za pomocą zrobotyzowanego urządzenia RevoScan}

\section{Streszczenie: W artykule zaprezentowano wyniki projektu badawczego zrealizowanego przez firmę} Terramap, którego efektem jest urządzenie pomiarowe do digitalizacji 3D, umożliwiające pozyskiwanie i przetwarzanie danych. Cechą charakterystyczną systemu jest automatyczne pozyskiwanie informacji zarówno o geometrii obiektu (digitalizacja przestrzenna) jak i informacji barwnej w przestrzeni RGB o tym obiekcie (wysokorozdzielcze zdjęcia cyfrowe). Dedykowane oprogramowanie dla urządzenia pozwala na planowanie i sterowanie procesem pozyskania danych, ich przetwarzanie oraz opracowanie materiału gotowego do prezentacji. Wdrożenie wyników przeprowadzonych badań przez skonstruowanie na ich podstawie urządzenia wraz z towarzyszącym oprogramowaniem pozwoliło na znaczne przyspieszenie prac digitalizacyjnych, a co za tym idzie obniżenie jednostkowych kosztów digitalizacji 3D. W celu oceny jakości geometrycznej uzyskanych automatycznie przez urządzenie modeli 3D wykonano, dla wybranych obiektów pomiary referencyjne. Pomiary zostały zrealizowane na dwa sposoby: po pierwsze wykonano pomiar geometrii obiektów testowych za pomocą ręcznego skanera 3D Artec Eva, po drugie wykonano bezpośredni manualny pomiar wymiarów charakterystycznych obiektów testowych z wykorzystaniem suwmiarki. Uzyskane modele 3D z urządzenia RevoScan i skanera 3D Artec Eva wpasowano w siebie, a następnie porównano za pomocą narzędzi oprogramowania Geomagic Qualify - moduły Alignment i Analysis. Wyniki manualnych pomiarów wymiarów charakterystycznych obiektów porównano z wynikami pomiarów tych samych cech zrealizowanymi na uzyskanych modelach 3D z urządzenia RevoScan. Uzyskane wyniki przedstawiono w formie tabel i wykresów. Wykonane badania potwierdzają osiągnięcie dokładności modelu lepszej niż 0,3 mm założonej w projekcie. 


\section{dr inż. Bartosz Mitka}

\section{bmitka@dephos.com}

Absolwent Akademii Górniczo-Hutniczej w Krakowie, Wydział Geodezji Górniczej i Inżynierii Środowiska. Doktor nauk technicznych w dziedzinie Geodezji i Kartografii. Ma bogate doświadczenie zawodowe uzyskane w trakcie wieloletniej pracy w firmach fotogrametrycznych w tym na stanowiskach menedżerskich. Specjalizuje się w fotogrametrii cyfrowej bliskiego zasięgu i naziemnym skaningu laserowym.

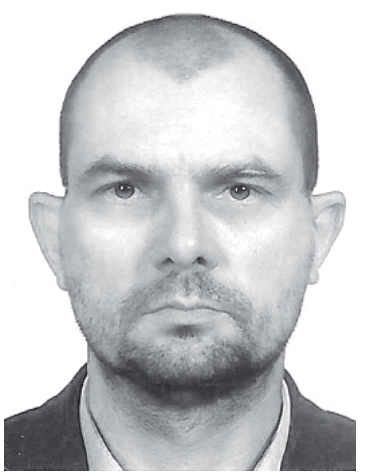

vspołautor portali internetowych prezentujących zdigitalizowane zbiory dla obiektów zabytkowych. Autor i współautor kilkudziesięciu publikacji z zakresu fotogrametrii i naziemnego skaningu laserowego. Zainteresowania naukowe: nowoczesne techniki pozyskiwania i przetwarzania danych geoprzestrzennych w szczególności w zakresie fotogrametrii cyfrowej i naziem nego skaningu laserowego oraz integracji danych pochodzacych z różnych źródeł. Od 2011 r. adiunkt w Katedrze Geodezji Rolnej, Katastru i Fotogra metrii Uniwersytetu Rolniczego w Krakowie. Opiekun Sekcji Fotogrametrii, Koła Naukowego Geodetów UR.

\section{mgr inż. Waldemar Bauer}

\author{
wbauer@dephos.com
}

Absolwent Informatyki Stosowanej na Wydziale Elektrotechniki, Automatyki, Informatyki i Elektroniki, Akademii Górniczo-Hutniczej w Krakowie. Obecnie słuchacz studiów doktoranckich w dyscyplinie Automatyka i Robotyka na Wydziale Elektrotechniki, Automatyki, Informatyki i Inżynierii Biomedycznej. Współpracuje od pięciu lat z firmą. mgr inż. Marcin Prochaska

\author{
mprochaska@dephos.com
}

Absolwent Akademii Górniczo-Hutniczej w Krakowie, Wydział Geodezji Górniczej i Inżynierii Środowiska. Współzałożyciel i Dyrektor d/s Rozwoju grupy DEPHOS (Terramap, Adram, Dephos Software) będącej pionierem na skanowanie laserowego i fotogrametrii cyfrowej na polskim rynku, szczególnie w zakresie inwentaryzacji obiektów zabytkowych. Ma ponad 20-letnie doświadczenie w projektowaniu i tworzeniu oprogra-

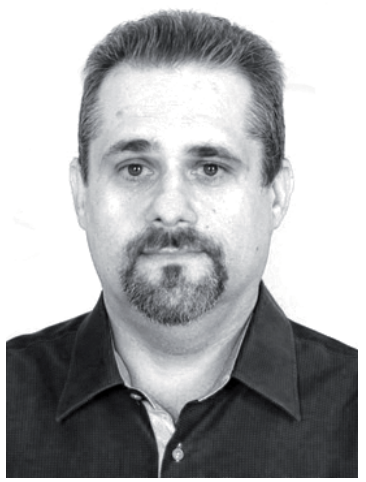
mowania dla potrzeb geodezili, fotogrametrii cyfrowej i skanowania laserowego. Współautor szeregu publikacji z zakresu fotogrametrii cyfrowej i skanowania laserowego.

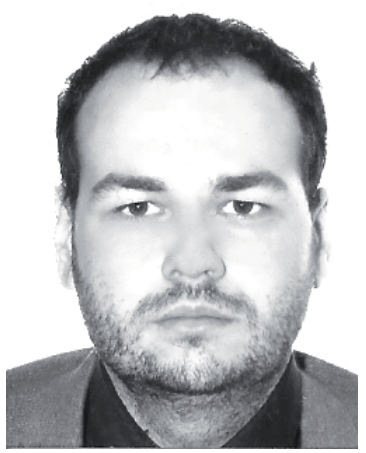

